\title{
Semi-automated high-throughput fluorescent intercalator displacement-based discovery of cytotoxic DNA binding agents from a large compound library
}

\author{
LaTeca S. Glass ${ }^{a}$, Aditi Bapat ${ }^{b}$, Mark R. Kelley ${ }^{b, c}$, Millie M. Georgiadis ${ }^{a, b,}{ }^{*}$, and Eric C. \\ Long ${ }^{a}{ }^{*}$ \\ aDepartment of Chemistry \& Chemical Biology, Purdue School of Science, Indiana University- \\ Purdue University Indianapolis, Indianapolis, IN 46202, USA
}

bepartment of Biochemistry \& Molecular Biology, Indiana University School of Medicine, Indiana University-Purdue University Indianapolis, Indianapolis, IN 46202, USA

'Department of Pediatrics (Section of Hematology/Oncology), Herman B. Wells Center for Pediatric Research, and Department of Pharmacology and Toxicology, Indiana University School of Medicine, USA

\begin{abstract}
High-throughput fluorescent intercalator displacement (HT-FID) was adapted to the semi-automated screening of a commercial compound library containing 60,000 molecules resulting in the discovery of cytotoxic DNA-targeted agents. Although commercial libraries are routinely screened in drug discovery efforts, the DNA binding potential of the compounds they contain has largely been overlooked. HT-FID led to the rapid identification of a number of compounds for which DNA binding properties were validated through demonstration of concentration-dependent DNA binding and increased thermal melting of A/T- or G/C-rich DNA sequences. Selected compounds were assayed further for cell proliferation inhibition in glioblastoma cells. Seven distinct compounds emerged from this screening procedure that represent structures unknown previously to be capable of targeting DNA leading to cell death. These agents may represent structures worthy of further modification to optimally explore their potential as cytotoxic anti-cancer agents. In addition, the general screening strategy described may find broader impact toward the rapid discovery of DNA targeted agents with biological activity.
\end{abstract}

\section{Keywords}

DNA binding; fluorescent intercalator displacement (FID); high-throughput screening; cytotoxicity

B-form DNA continues to be an important and viable target in the discovery and development of novel anti-cancer ${ }^{1-6}$ and anti-microbial/anti-parasitic ${ }^{7-9}$ agents. Indeed, it has been noted ${ }^{2}$ that among new agents in clinical use against cancer (as of 2002), many continue to target DNA

\footnotetext{
(C) 2010 Elsevier Ltd. All rights reserved.

*Corresponding authors. Tel.: +1 317274 6888; fax: + 1 317-274-4701 (E.C.L.), Tel.: +1 317 278-8486 (M.M.G.), eclong@ iupui.edu (E.C. Long), mgeorgia@iupui.edu (M.M. Georgiadis).

Publisher's Disclaimer: This is a PDF file of an unedited manuscript that has been accepted for publication. As a service to our customers we are providing this early version of the manuscript. The manuscript will undergo copyediting, typesetting, and review of the resulting proof before it is published in its final citable form. Please note that during the production process errors may be discovered which could affect the content, and all legal disclaimers that apply to the journal pertain.
} 
as a locus for their activities. ${ }^{10}$ In general, biologically active DNA-targeted compounds, either wholly synthetic or derived from natural product sources, bind DNA reversibly or modify this biopolymer covalently leading to the inhibition of transcription and/or DNA replication; while reversible DNA binding agents can interfere competitively with the proteins necessary for transcriptional control or processing, covalent lesions can lead to intra- or inter-strand cross links within genomic DNA, often halting the progression of replication forks. Additionally, in the case of DNA-targeted anti-parasitic compounds, e.g., anti-trypanosomals, active agents often target A/T-rich regions of DNA including intrinsically bent kinetoplast minicircles. ${ }^{4,8}$ Thus, given the clinical potential of DNA targeted agents-from the generation of novel anticancer treatments to unique strategies in the fight against microbial infections and neglected tropical diseases-the search for new DNA binding agents continues unabated.

Expediting the above search, high-throughput screening (HTS) strategies coupled to focused compound library approaches are being employed with increasing frequency. ${ }^{3,5,11,12}$ To date, most efforts in this area have aimed for the discovery of increasingly selective compounds targeted to key DNA sequences within genes, usually the binding sites of critical regulatory proteins. ${ }^{3,5}$ These efforts have been facilitated by the development of strategies to rapidly identify site-selective DNA binding agents and to assess their DNA binding properties. Among the methods employed, fluorescence intercalator displacement (FID) ${ }^{13-15}$ and cognate site identifier (CSI) arrays ${ }^{16}$ have been used successfully. Noteworthy, the FID and CSI strategies have been combined recently into a single platform for discovery. ${ }^{17}$

While highly selective DNA binding agents discovered through the above efforts generally are pursued to enable the "knock out" of key DNA-protein interactions to ultimately alter some well-defined biological response, it is worth underscoring that virtually all DNA-targeted agents in active clinical use exhibit very limited site-selectivities, usually 2-4 base pairs only. 18,19 Thus, while efforts aimed at developing agents with increasing DNA specificity are of keen interest, the continued quest for unique biologically active agents with limited DNA siteselectivities may similarly lead to interesting and useful compounds.

With the above in mind, we have developed a strategy for the rapid discovery of DNA targeted compounds that couples fluorescent intercalator displacement (FID) to semi-automated highthroughput screening technologies (Scheme 1). We demonstrate that a robust HT screen can be developed to analyze large compound libraries, as demonstrated through our analysis of a 60,000 member commercially-available library, and that validated DNA-targeted hits discovered in this fashion can lead to agents that are cytotoxic to glioblastoma cancer cells. While the primary goal of the work described herein was to develop a strategy to expedite the identification of DNA targeted agents from large libraries, as a side benefit our assay also provides a rapid means to pre-screen for DNA binding library members that may lead to falsepositive results in assays devoted to the discovery of agents targeted to proteins in the presence of a DNA substrate, e.g. enzymes involved in repair processes.

\section{HTS assay development and validation}

Our HTS strategy was developed from a standard FID approach using calf thymus DNA as a binding substrate and ethidium bromide as a reporting fluorophore. ${ }^{20}$ Calf thymus DNA has the advantage of being a cost-effective HTS substrate approximating all possible combinations of base pairs. Briefly, in an FID assay, DNA-bound ethidium bromide fluoresces brightly and when challenged with a competing DNA binding agent, the original level of ethidium bromide fluorescence is decreased due to its displacement from binding sites.

Initially, we sought to assess the validity of our proposed assay. Using ethidium-bound calf thymus DNA in conjunction with two well-characterized DNA binding agents, actinomycin $\mathrm{D}$ and netropsin (as $\mathrm{G} / \mathrm{C}$-selective intercalating and $\mathrm{A} / \mathrm{T}$-selective groove-binding positive 
controls, respectively), or a buffer blank (as a negative control), $Z^{\prime}$ score ${ }^{21}$ analyses were conducted. $Z^{\prime}$ analyses provide a statistical assessment of the reproducibility achievable in an HT assay: the negative control provides a maximum percent $F$ to be expected in the assay while positive controls provide a maximum decrease in $\mathrm{F}$ to be expected from strong DNA binding agents-these aspects determine the dynamic range of the assay.

Using the above controls, $20 \mu \mathrm{L}$ aliquots containing $25 \mu \mathrm{M}$ compound (or water blanks) were dispensed into 384 well plates (black Nunc) using a robotic liquid handler (Tecan Freedom EVO 150). Subsequently, $30 \mu \mathrm{L}$ aliquots of a solution containing calf thymus DNA, ethidium bromide, and Tris buffer ( $\mathrm{pH}$ 7.4) were dispensed into these same plate wells to provide final concentrations of each well component ( $21 \mu \mathrm{M}$ DNA base pair, $6.5 \mu \mathrm{M}$ ethidium bromide, 100 $\mathrm{mM} \mathrm{NaCl}, 10 \mathrm{mM}$ Tris (pH 7.4), $0.8 \%$ DMSO and $10 \mu \mathrm{M}$ binding agent. The fluorescence output of each sample well was measured via a Perkin-Elmer Envision 2102 multilabel plate reader $\left(\lambda_{\mathrm{ex}} 530 \mathrm{~nm}, \lambda_{\mathrm{em}} 615 \mathrm{~nm}\right.$ ) and compared to negative controls (no added compound) to determine percent $\mathrm{F}$ decreases. These data ( $\sim 384$ wells, one plate, per positive or negative agent) revealed that the average percent decrease in F observed for actinomycin D was $63 \%$ while that observed for netropsin was $32 \%$. Using these data a $Z^{\prime}$ score of 0.74 was determined for actinomycin $\mathrm{D}$, well within the acceptable range for $\mathrm{Z}^{\prime}$ scores $(>0.5$ to be deemed a viable assay ${ }^{21}$ ) and indicating the viability of our screen. In comparison, a $Z^{\prime}$ score of 0.41 was determined for netropsin; actinomycin D thus was chosen as the exclusive positive parallel control for all subsequent FID screening.

\section{Application to a compound library}

The assay was applied to a commercially available ChemDiv library containing 60,000 compounds with an overall average MW of 300. ChemDiv libraries are widely used in HTS and contain a cross-section of pharmacophore-rich, drug-like compounds that possess good ADME profiles. Noteworthy, the DNA binding potential of this library has not been assessed. Thus, identifying the DNA binding components contained therein may be of broader interest.

Applying our screen to the above library $\left(\sim 10 \mu \mathrm{M}\right.$ compound/well $\left.{ }^{22}\right)$ in the presence of both positive (actinomycin D) and negative (buffer blank) controls revealed that from among the 60,000 compounds examined, 165 produced an F decrease of $25 \%$ or greater (Scheme 1) with the best agents decreasing $\mathrm{F}$ between $46 \%$ and $30 \%$. Next, from among the 165 compounds initially identified, 143 available compounds were rescreened twice in independent experiments using the same FID assay. The re-screens led to the identification of 57 compounds for which consistent results were obtained and from which 30 compounds were selected for validation using a non-fluorescence based method.

\section{Validation of hits: non-fluorescent based secondary screening via thermal melting}

The DNA binding activities of the 30 hits identified above were verified using a standard, nonfluorescence based method: DNA thermal melting. ${ }^{20} \Delta T_{\mathrm{m}}$ values were determined through an examination of DNA hyperchromicity at $260 \mathrm{~nm}$ as a function of increased temperature in the presence of each compound. Upon examination of the 30 hits (in parallel with actinomycin and netropsin controls) using poly(dA-dT) and a G/C-rich oligonucleotide (to evaluate A/Tvs. G/C-selectivity, respectively), we confirmed the DNA binding activity of 17 of the original 30 compounds. From these 17 verified DNA binding agents, seven compounds where selected (1-7, see Fig 1 and Table 1) based on their consistent, strong FID assay responses and high $T_{\mathrm{m}}$ values, quite similar to actinomycin and netropsin, and similar in $T_{\mathrm{m}}$ behavior to some synthetic groove binding ligands reported previously by others using this DNA. ${ }^{23}$ 
As shown in Table 1, 1-7 all displayed appreciable $\% \mathrm{~F}$ changes in the HT-FID screen relative to actinomycin and netropsin. The top compounds selected also exhibited high $\Delta T_{\mathrm{m}}$ values quite similar to the values observed for the control DNA binding agents. While not definitive, the differential responses of these agents towards the thermal melting substrates suggested that 1-6 may be A/T-selective while 7 may be relatively more selective for G/C sites: like the A/ T-selective agent netropsin, 1-6 exhibited no impact on the thermal melting of the G/C oligonucleotide while increasing the $T_{\mathrm{m}}$ of the A/T substrate; whereas, 7 behaved in a fashion similar to actinomycin with the G/C oligonucleotide but did not impact the melting of the A/ $\mathrm{T}$ substrate. A precise determination of the DNA binding site-selectivities of these agents will require more rigorous testing.

\section{Determination of relative DNA binding affinities}

The relative DNA binding affinities of 1-7 were determined using plate conditions (DNA, buffer, etc.) similar to those used in the FID screening. ${ }^{24}$ Thus, the concentrations of each compound 1-7 required to decrease sample fluorescence to half its original value $\left(\mathrm{FD}_{50}\right)$ within the range achievable by each compound were determined (Table 1). Realizing that at this point in our characterization we do not know: (1) the DNA-binding site sizes associated with these compounds nor (2) their selectivities beyond tentatively establishing A/T vs. G/C preferences, two factors that influence the extent of ethidium bromide displacement, it appears that compounds 1-7 as a group are reasonably strong DNA-binding agents relative to the control agents studied in parallel. Obviously, a detailed DNA binding characterization through established techniques is beyond the scope and intention of this report focused on strategies for rapid discovery.

\section{Assessments of cell growth inhibition and cytotoxicity}

Along with their in vitro DNA binding, the relative cell growth inhibition/cytotoxicities of 1-7 against SF767 glioblastoma cells were also evaluated. Cell growth and survival assays were determined in triplicate using a standard MTT (3-(4,5-dimethylthiazol-2-yl)-2,5diphenyltetrazolium) assay ${ }^{25}$ : cells (2000) grown for $24 \mathrm{~h}$ were treated with increasing concentrations of 1-7; cell survival after $72 \mathrm{~h}$ of treatment was determined by addition of the MTT reagent and standard protocols to assess the remaining number of viable cells. A mediaonly blank was included in each treatment group to serve as a background control. Fig 2 illustrates the \% surviving cells after $72 \mathrm{~h}$ of treatment at a given compound concentration; plots were used to graphically determine $\mathrm{LC}_{50}$ values (Table 1 ). Compounds 2-6 inhibited cell growth while $\mathbf{1}$ and $\mathbf{7}$ showed no significant effect at the concentrations tested. Compound $\mathbf{2}$ produced the lowest $\mathrm{LC}_{50}$ value of $2.6 \mu \mathrm{M}$, while 4 and 5 , the latter resembling a benzimidazolebased DNA groove binder, exhibited the next lowest $\mathrm{LC}_{50}$ values. In comparison to the above, $\mathbf{3}$ and $\mathbf{6}$ produced intermediate results.

\section{Conclusions}

We have described a semi-automated FID-based HT screen for the rapid discovery of DNA binding components from compound libraries. This screen has the potential to be widely applicable in the discovery of new DNA binding agents as well as to permit the pre-screening of libraries when knowledge of the presence of DNA binding components would be useful. It is evident that this screen can select diverse and unique DNA binding structures, as in our discovery of 1-7. Indeed, a perusal of the literature indicates that DNA binding properties and cytotoxicities have not been reported for the compounds selected. Currently, structure-activity relationships for these compounds are being assessed as well as more detailed analyses of their DNA binding characteristics. 


\section{Acknowledgments}

We gratefully acknowledge support from an IUPUI Research Support Funds Grant (to E.C.L.) and the NIH (M.R.K: CA94025, CA106298 and CA121168). Screening was carried out at the Chemical Genomics Core Facility within the IU School of Medicine at IUPUI.

\section{References and notes}

1. Thurston DE. Br J Cancer 1999;80(Suppl 1):65. [PubMed: 10466765]

2. Tse WC, Boger DL. Chem Biol 2004;11:1607. [PubMed: 15610844]

3. Dickinson LA, Burnett BS, Melander C, Edelson BS, Arora PS, Dervan PB, Gottesfeld JM. Chem Biol 2004;11:1583. [PubMed: 15556009]

4. Wilson WD, Nguyen B, Tanious FA, Mathis A, Hall JE, Stephens CE, Boykin DW. Curr Med Chem: Anti-Cancer Agents 2005;5:389.

5. Stover JS, Shi J, Jin W, Vogt PK, Boger DL. J Am Chem Soc 2009;131:3342. [PubMed: 19216569]

6. Rahman KM, Thompson AS, James CH, Narayanaswamy M, Thurston DE. J Am Chem Soc 2009;131 asap article.

7. Tidwell, RR.; Boykin, DW. Small Molecule DNA and RNA Binders. Demeunynck, M.; Bailly, C.; Wilson, WD., editors. Vol. 2. Wiley-VCH; Weinheim: 2003. p. 414-460.

8. Wilson WD, Tanious FA, Mathis A, Tevis D, Hall JE, Boykin DW. Biochimie 2008;90:999. [PubMed: 18343228]

9. Glass LS, Nguyen B, Goodwin KD, Dardonville C, Wilson WD, Long EC, Georgiadis MM. Biochemistry 2009;48:5943. [PubMed: 19405506]

10. Newman DJ, Cragg GM, Snader KM. J Nat Prod 2003;66:1022. [PubMed: 12880330]

11. Boger DL, Fink BE, Hedrick MP. J Am Chem Soc 2000;122:6382.

12. Boger DL, Dechantsreiter MA, Ishii T, Fink BE, Hedrick MP. Bioorg Med Chem 2000;8:2049. [PubMed: 11003149]

13. Tse WC, Boger DL. Acc Chem Res 2004;37:61. [PubMed: 14730995]

14. Chaltin P, Borgions F, Van Aerschot A, Herdewijn P. Bioorg Med Chem Lett 2003;13:47. [PubMed: 12467614]

15. Lewis MA, Long EC. Bioorg Med Chem 2006;14:3481. [PubMed: 16439138]

16. Warren CL, Kratochvil NC, Hauschild KE, Foister S, Brezinski ML, Dervan PB, Phillips GN Jr, Ansari AZ. Proc Natl Acad Sci U S A 2006;103:867. [PubMed: 16418267]

17. Hauschild KE, Stover JS, Boger DL, Ansari AZ. Bioorg Med Chem Lett 2009;19:3779. [PubMed: 19435662]

18. Reddy PBS, Sondhi SM, Lown JW. Pharmacol Ther 1999;84:1. [PubMed: 10580832]

19. Yang X-L, Wang AH-J. Pharmacol Ther 1999;83:181. [PubMed: 10576292]

20. Fox, KR. Drug-DNA Interaction Protocols: Methods in Molecular Biology. Vol. 90. Humana; Totowa, NJ, USA: 1997.

21. Zhang JH, Chung TD, Oldenburg KR. J Biomol Screen 1999;4:67. [PubMed: 10838414]

22. The commercial plated stocks used for HTS contain approximately $25 \mu \mathrm{M}$ solutions of each library member based on an overall average MW of 300.

23. Ismail MA, Batista-Parra A, Miao Y, Wilson WD, Wenzler T, Brun R, Boykin DW. Bioorg Med Chem 2005;13:6718. [PubMed: 16099661]

24. Stock solutions for this aspect of the work were prepared gravimetrically from solid compound sources-the results shown in Table 1 for $\mathrm{FD}_{50}$ and Range $\% \mathrm{~F}$ can thus be viewed as a more accurate representation of the relative binding abilities of these compounds. Sample wells were prepared as in the original screen; however, aliquots of compound 1-7 were added to a series of wells to achieve final concentrations within the range of $0.1-50 \mu \mathrm{M}$.

25. Mosmann T. J Immunol Methods 1983;65:55. [PubMed: 6606682] 

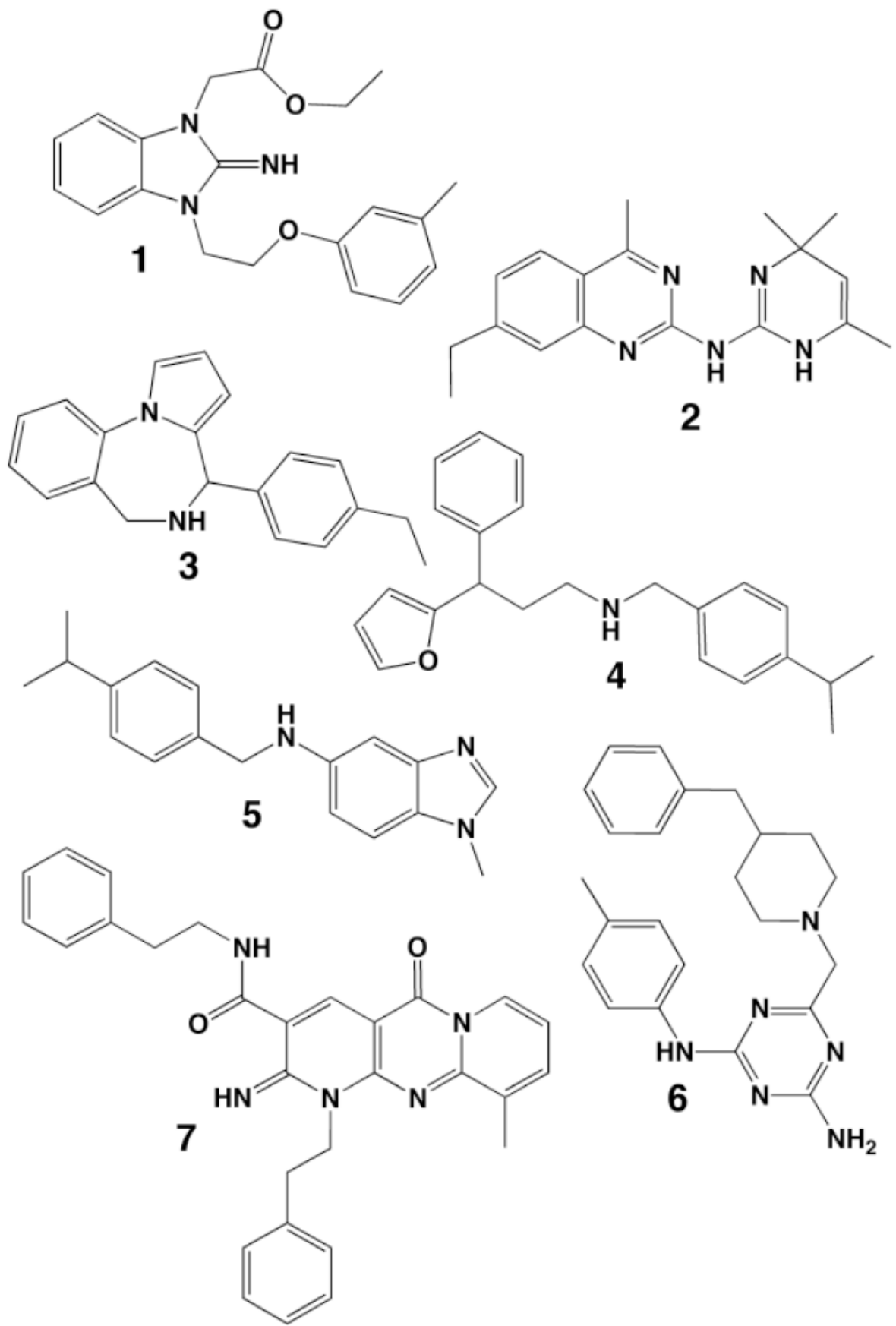

Figure 1.

Structures of select validated DNA binding hits 1-7 discovered as described in Scheme 1. 


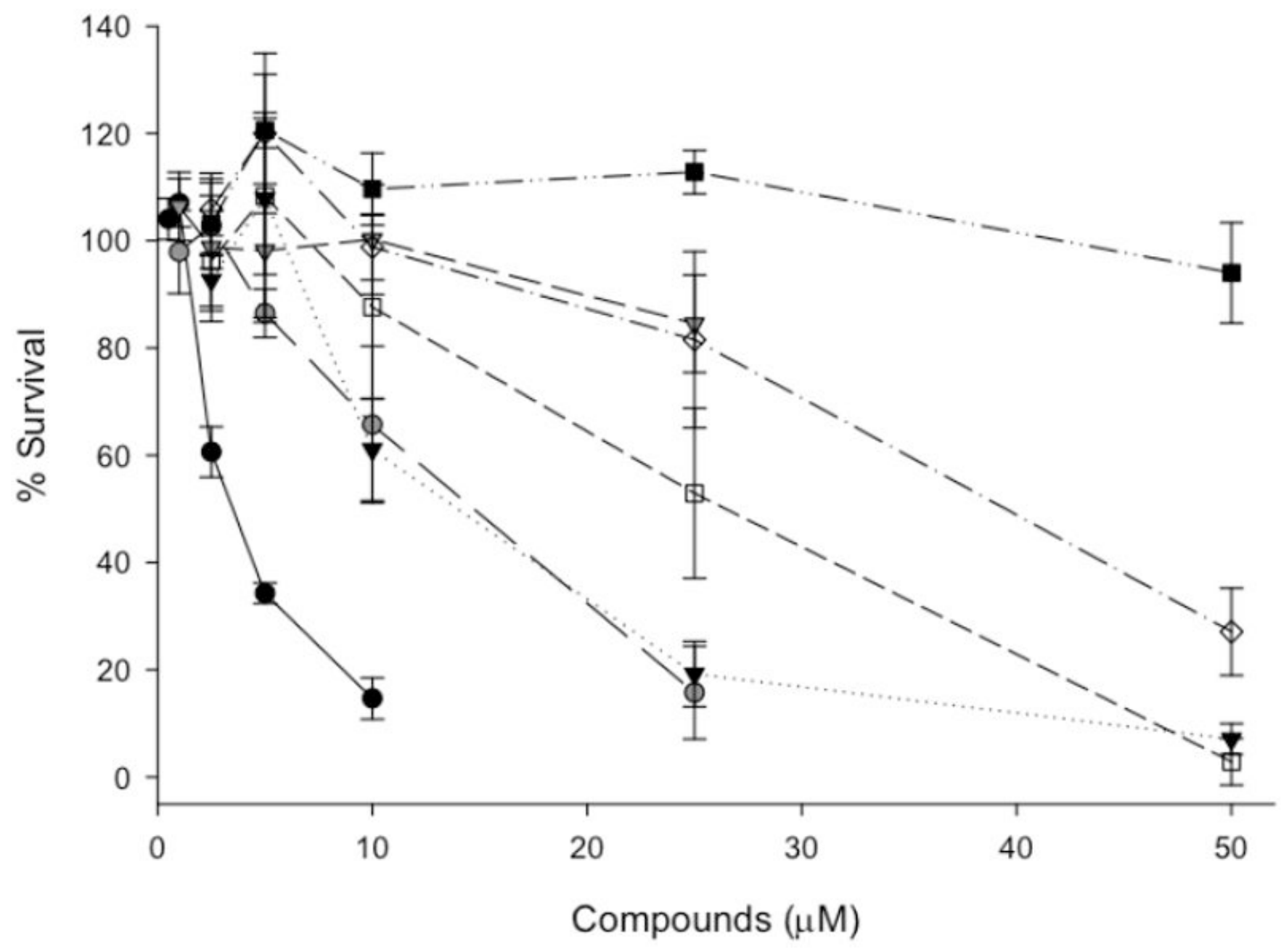

Figure 2.

Results from MTT assays that examined the \% survival of SF767 glioblastoma cells treated for 72 hours with increasing concentrations of 1-7 (1: black squares; 2: black circles; 3 : white diamonds; 4: grey circles; $\mathbf{5}$ : black triangles; $\mathbf{6}$ : white squares; 7 : grey triangles). These data were used to determine $\mathrm{LC}_{50}$ values (Table 1). 


\section{Chemical Library} 60,000 members

HT-FID screen

165 Compounds

(with $\mathrm{F}$ decrease of $>25 \%$ )

HT-FID rescreen of 143/165

57 Compounds

unique/representative structures

\section{Compounds}

DNA $T_{m}$ secondary screen/ hit validation

\section{Validated DNA Binding Compounds}

\section{Compounds \\ Selected for further biological testing}

Scheme 1.

Semi-automated high-throughput screening strategy leading to the selection of DNA binding components from a compound library. 


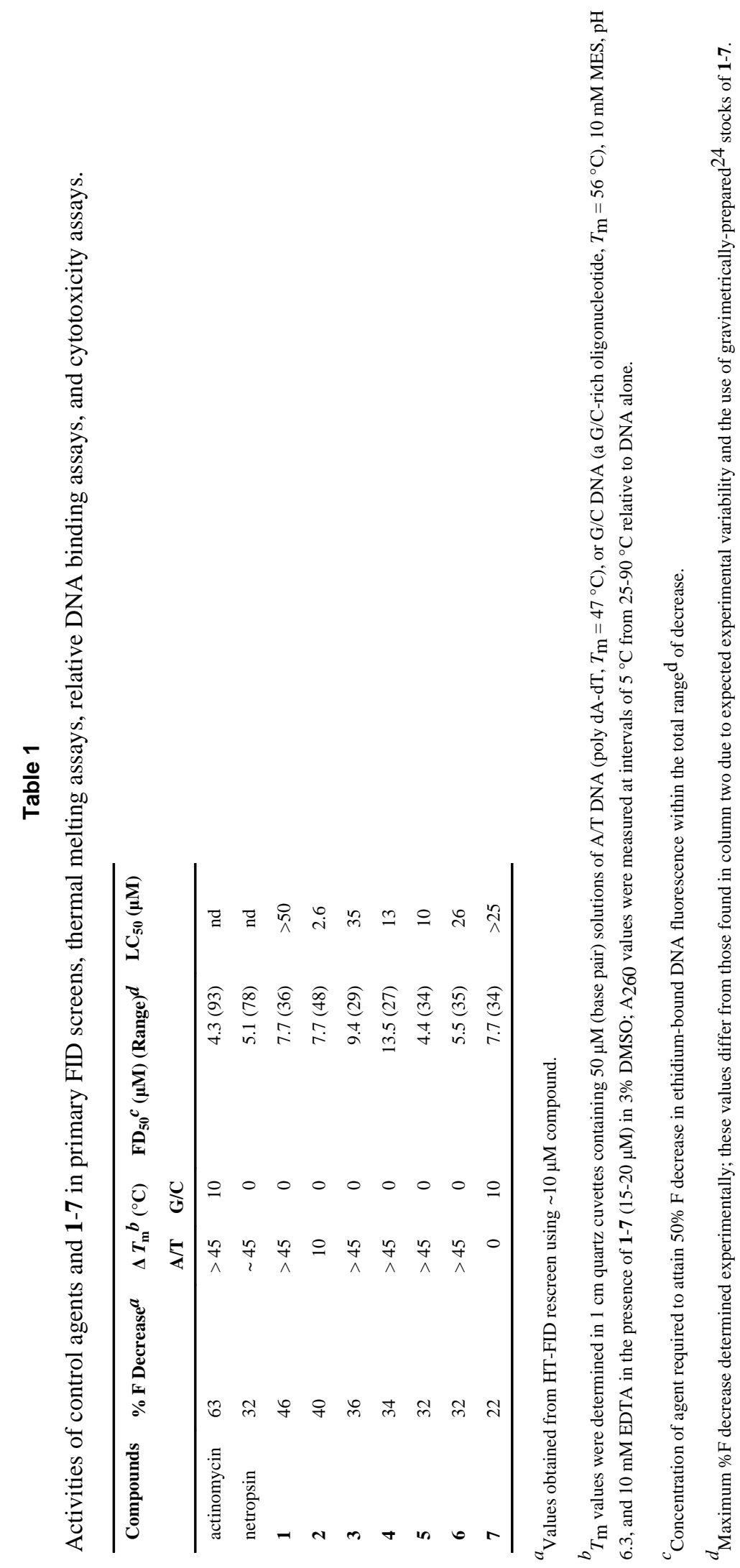

Bioorg Med Chem Lett. Author manuscript; available in PMC 2011 March 1. 